\title{
PERAN KOMITE SEKOLAH DALAM MENINGKATKAN MUTU PENDIDIKAN DI PONDOK PESANTREN MODERN TERPADU TUANKU LINTAU KABUPATEN TANAH DATAR
}

\author{
Laminsar \\ Penyuluh Agama di Kantor Urusan Agama Kecamatan Lintau Buo \\ $-20$
}

\begin{abstract}
Peran komite sekolah dalam meningkatkan mutu pendidikan di pondok pesantren modern terpadu tuanku lintau kabupaten tanah datar. This research intent for revealing problem that gets bearing with schooled committee role in upgrade education quality at at Intergraited Muslim Boarding School Modern of Tuanku Lintau.

To get observational problem answer that therefore formulated 4 focus sub that will be tested (1) Committee Role as Giving As judgments (2) Committee Role as Supporting As (3) Committee Role as Supervisor (4) Committee Role as Mediator. Respondent in research is integraited muslim boarding school headmaster of tuanku Lintau and therewith chairman governing Intergraited Muslim Boarding School Modern of Tuanku Lintau. whereas data collecting tech with observation, interview and studi documents gather trick data with data reduction, data representation, conclusion pull or analyzed

That analyzed point out result committee role in upgrade education quality intergraited muslim boarding school modern of tuanku Lintau stills was maximal because of a lot of administrator and member that don't active, but although is role such committee makes a abode to walk both as judgment giver, supporting, supervisor and as mediator so gets implication to medium development velocity and utilised premedium education upgrade at intergraited muslim boarding school modern of tuanku Lintau.
\end{abstract}

Kata Kunci: Komite Sekolah, meningkatkan mutu.

\section{PENDAHULUAN}

Pelaksanaan peran komite sekolah/ pondok pesantren masih sangat variatif. $\mathrm{Di}$ satu pihak ada komite sekolah yang masih melanjutkan peran BP3 (Badan Pembantu Penyelenggara Pendidikan) yang sering disebut sebagai "stempel” kepala sekolah. Artinya, komite sekolah seperti ini hanya "mengekor" apa yang diprogramkan oleh kepala sekolah . Komite sekolah/pondok pesantren tidak memiliki ide kreatif dan gagasan inovatif untuk meningkatkan hasil belajar siswa. Jadi program kepala sekolah/ pondok pesantren itulah yang menjadi program komite sekolah/pondok pesantren. Sebaliknya adapula komite sekolah/pondok 
pesantren yang justru sangat ditakuti oleh kepala sekolah/pondok pesantren.

Kedudukan sebagai kepala sekolah/ pondok pesantren sering menjadi incaran kritik dan pengawasan secara berlebihan oleh komite sekolah/pondok pesantren apalagi jika kepala sekolah/pondok pesantren tersebut melaksanakan tugasnya secara tidak transparan, demokratis dan akuntabel. Jika kepala sekolah jelas-jelas melakukan penyelewengan maka komite sekolah/ pondok pesantren ini tidak segan-segan lagi mengajukan rekomendasi kepada dinas pendidikan untuk mengganti kepala lembaga pendidikan tersebut. (E.Mulyasa,2002: 2)

Peran sebagai badan pengawasan lebih menonjol dibandingkan dengan yang lain. Bahkan di beberapa pondok pesantren keberadaan lembaga ini justru menjadi saingan kepala sekolah/pondok pesantren dalam menentukan kebijakan sekolah/ pondok pesantren.

Adapun permasalahan yang diangkat dalam tulisan ini adalah: Bagaimana Peran Komite Sekolah dalam Meningkatkan Mutu Pendidikan di Pondok Pesantren Modern Terpadu Tuanku Lintau Kabupaten Tanah Datar? Sedangkan yang jadi sub masalahnya adalah:

1. Bagaimana peran komite sebagai pemberi pertimbangan dalam penyelenggaraan pendidikan di satuan pendidikan guna meningkatkan mutu pendidikan di Pondok Pesantren Modern Tuanku Lintau?
2. Bagaimana peran komite sebagai pendukung baik yang berwujud finansial, pemikiran, maupun tenaga dalam penyelenggaraan pendidikan di satuan pendidikan guna meningkatkan mutu pendidikan di Pondok Pesantren Modern Tuanku Lintau?

3. Bagaimana peran komite sebagai pengontrol dalam rangka transparansi dan akuntabilitas penyelenggaraan dan keluaran pendidikan di satuan pendidikan guna meningkatkan mutu pendidikan di Pondok Pesantren Modern Tuanku Lintau.?

4. Bagaimana peran komite sebagai mediator antara pemerintah dengan masyarakat di satuan pendidikan guna meningkatkan mutu pendidikan di Pondok Pesantren Modern Tuanku Lintau?

Penelitian ini adalah penelitian lapangan dengan menggunakan pendekatan kualitatif. Dalam penelitian ini data yang hendak dikumpulkan adalah tentang Peran Komite Sekolah dalam Meningkatkan Mutu Pendidikan di Pondok Pesantren Modern Terpadu Tuanku Lintau Kabupaten Tanah Datar. Data yang dibutuhkan dalam penelitian ini adalah Informasi yang bersifat deskriptif, karena itulah penelitian ini menggunakan pendekatan kualitatif.

\section{PEMBAHASAN}

\section{Peran Komite Sekolah}

Komite sekolah mempunyai penjabaran peran dalam kegiatan operasional komite 
sekolah, adapun penjabarannya adalah sebagai berikut: (Sukron, www, pendidikan. net, dalam Gooegle. com. 2005)

a. Peran komite sekolah sebagai pemberi pertimbangan (advisory agency).

Indikator kinerjanya peran komite sekolah sebagai pemberi pemberi pertimbangan adalah dengan memberikan masukan dan pertimbangan mengenai; Kebijakan pendidikan, Program Pendidikan, Rancangan Anggaran Pendapatan dan Belanja Sekolah (RAPBS), Kriteria kinerja satuan, Kriteria tenaga kependidikan, Kriteria fasilitas pendidikan.

Sebagai pemberi pertimbangan (advisory agency) dalam penentuan dan pelaksanaan kebijakan di satuan pendidikan perannya meliputi:

1) Perencanaan sekolah

2) Pelaksanaan program

3) Pengelolaan sumber daya pendidikan

b. Peran komite sekolah sebagai pendukung (supporting agency).

Peran komite sekolah sebagai pendukung (supporting agency) indikator kinerjanya yaitu:

1) Mendorong orang tua untuk berpartisipasi dalam pendidikan.

2) Mendorong masyarakat berpartisipasi dalam pendidikan.

3) Menggalang dana dalam rangka pembiayaan pendidikan.
4) Mendorong tumbuhnya perhatian masyarakat terhadap penyelenggaraan pendidikan yang bermutu

5) Mendorong tumbuhnya komitmen masyarakat terhadap penyelenggaraan pendidikan yang bermutu.

Peran komite sekolah sebagai pendukung (supporting agency) meliputi:

1) Pengelolaan sumber daya

2) Pengelolaan sarana dan prasarana

3) Pengelolaan anggaran

Peran komite sekolah sebagai pengontrol (controlling agency)

Peran komite sekolah sebagai pengontrol (controlling agency) indikator kinerjanya yaitu:

1) Melakukan evaluasi dalam setiap kegiatan.

2) Melakukan pengawasan terhadap kebijaksanaan program penyelenggaraan pendidikan.

3) Melakukan pengawasan terhadap kebijaksanaan program keluaran pendidikan.

Peran komite sekolah sebagai pengontrol (controlling agency) meliputi:

1) Mengontrol perencanaan program sekolah

2) Memantau pelaksanaan program.

c. Peran komite sekolah sebagai mediator.

Peran komite sekolah sebagai mediator indikator kinerjanya yaitu: 
1) Melakukan kerja sama dengan masyarakat

2) Menampung aspirasi, ide, tuntutan dan berbagai kebutuhan pendidikan yang diajukan oleh masyarakat

3) Menganalisis aspirasi, ide, tuntutan dan berbagai kebutuhan pendidikan yang diajukan oleh masyarakat.

Peran komite sekolah sebagai mediator meliputi mediator antara pemerintah (executive), dunia usaha dan Lembaga Swadaya Masyarakat (LSM) dengan masayrakat di satuan pendidikan.

\section{Mutu Pendidikan}

Mutu dalam konteks "hasil" pendidikan mengacu pada prestasi yang dicapai oleh lembaga pendidikan pada setiap kurun waktu tertentu. Prestasi yang dicapai atau hasil pendidikan (student achievement) dapat berupa hasil tes kemampuan akademis, dapat pula prestasi bidang lain seperti olah raga, seni atau keterampilan tertentu (komputer, beragam jenis teknik, jasa). Bahkan prestasi lembaga pendidikan dapat berupa kondisi yang tidak dapat dipegang (intangible) seperti suasana disiplin, keakraban, saling menghormati, kebersihan, dan sebagainya ungkap Umaedi. (Umaedi. 1999; 9)

Pengertian mutu secara umum adalah gambaran dan karakteristik yang menyeluruh dari barang-barang dan jasa yang menunjukkan kemampuannya dalam memuaskan kebutuhan yang ditentukan dalam konteks pendidikan. Pengertian mutu mencakup Input, proses dan output pendidikan. (Depdiknas. 2001)

\section{Peran Komite Sekolah dalam Meningkatkan Mutu Pendidikan}

Peran komite sekolah dalam meningkatkan mutu pendidikan merupakan turut sertanya individu atau kelompok masyarakat dalam pengembangan sekolah. Selanjutnya peran komite sekolah adalah suatu perwujudan perilaku masyarakat yang positif dalam suatu rangkaian kerjasama atau keterlibatan dalam pelaksanaan hubungan sekolah dengan masyarakat. Yang dimaksud dengan keterlibatan di sini bahwa masyarakat ikut serta secara lansung, baik secara fisik maupun melalui konsentrasi uang, barang, sumbangan pikiran sekaligus ikut serta mengelola dan bertanggung jawab terhadap hasil-hasil hubungan sekolah dengan masyarakat yang dicapainya.

Partisipasi masyarakat sebagai kekuatan kontrol dalam pelaksanaan berbagai program pemerintah menjadi sangat penting. Dibidang pendidikan partisipasi ini lebih strategis lagi. Sebab, partisipasi tersebut bisa menjadi semacam kekuatan kontrol bagi pelaksanaan dan kualitas mutu pendidikan di sekolah-sekolah.

Apalagi saat ini Depdiknas mulai menerapkan konsep manajemen berbasis sekolah. Karena itulah gagasan tentang perlunya komite sekolah yang berperan sebagai lembaga yang menjadi mitra sekolah yang menyalurkan partisipasi masyarakat menjadi kebutuhan yang sangat nyata 
dan tidak terhindarkan. Dengan adanya komite sekolah, kepala sekolah dan para penyelenggara serta pelaksana pendidikan di sekolah secara substansial akan bertanggung jawab kepada komite sekolah tersebut.

Peran Komite sekolah juga dapat memberikan masukan penilaian untuk pengembangan pelaksanaan pendidikan dan pelaksanaan manajemen sekolah. Komite sekolah bisa juga memberikan masukan bagi pembahasan atas usulan Rencana Anggaran Pendapatan dan Belanja Sekolah (RAPBS).

Menurut Sutamto peran atau partisipasi komite Sekolah diantaranya:

a. Membantu meningkatkan kelancaran penyelenggaraan kegiatan belajarmengajar di sekolah baik sarana, prasarana maupun teknis pendidikan.

b. Melakukan pembinaan sikap dan perilaku siswa. Membantu usaha pemantapan sekolah dalam mewujudkan pembinaan dan pengembangan ketakwaan terhadap Tuhan Yang Maha Esa, pendidikan demokrasi sejak dini (kehidupan berbangsa dan bernegara, pendidikan pendahuluan bela negara, kewarganegaraan, berorganisasi, dan kepemimpinan), keterampilan dan kewirausahaan, kesegaran jasmani dan berolah raga, daya kreasi dan cipta, serta apresiasi seni dan budaya.

c. Mencari sumber pendanaan untuk membantu siswa yang tidak mampu.

d. Melakukan penilaian sekolah untuk pengembangan pelaksanaan kurikulum, baik intra maupun ekstrakurikuler dan pelaksanaan manajemen sekolah, kepala/ wakil kepala sekolah, guru, siswa, dan karyawan.

e. Memberikan penghargaan atas keberhasilan manajemen sekolah.

f. Melakukan pembahasan tentang usulan Rancangan Anggaran Pendapatan dan Belanja Sekolah (RAPBS) dan

g. Meminta sekolah agar mengadakan pertemuan untuk kepentingan tertentu. (Sutamto.2010; (http://sutamto. wordpress.com. Diakses 17 Juni 2011).

Sedangkan menurut Tjokroamidjo (dalam Rahmat) ada empat aspek penting partisipasi komite sekolah (masyarakat) dalam meningkatkan mutu pendidikan yaitu:

a. Terlibatnya masyarakat(komite sekolah), serta ikut serta dalam menentukan arah, stratagi, dan kebijakan sekolah.

b. Meningkatkan kemampuan untuk merumuskan tujuan- tujuan.

c. Partisipasi masyarakat dalam kegiatankegiatan yang konsisten dengan arah, strategi, dan rencana yang telah ditentukan, dan,

d. Adanya perumusan dan pelaksanaan program- program partisipasi dalam sekolah berencana, yang secara lansung memberikan dan menyangkut kesejahteraan masyarakat. (Abdul Rahmat. 2009 ;81-82) 
Dari pernyataan di atas dapat disimpulkan bahwa dalam partisipasi terdapat unsur- unsur yang penting, antara lain:

a. Keterlibatan mental,emosi dan dengan sendirinya fisik.

b. Kehendak sendiri atau prakarsa untuk mengambil bagian di dalam usaha pencapaian tujuan.

c. Swadaya dan,

d. Rasa tanggung jawab. Oleh karena itu partisipasi komite sekolah dapat dikatakan sebagai suatu proses penyaluran aspirasi masyarakat baik yang bersifat dukungan material maupun non material dari seluruh anggota dan kepengurusannya, baik secara individual maupun kolektif, secara langsung maupun tidak langsung dalam perencanaan, pengambilan keputusan dan pembuatan kebijakan, pelaksanaan, serta pengawasan/ pengevaluasian pendidikan demi kemajuan mutu sekolah.

\section{Profil Pondok Pesantren Tabiyah}

\section{Islamiyah Pariangan}

Pondok Pesantren Modern Terpadu Tuanku Lintau merupakan Pondok Pesantren yang didirikan oleh Yayasan Pembangunan Nagari Tepi Selo didirikan pada tanggal 20 Juli 1998 di atas tanah seluas $504 \mathrm{~m} 2$ dengan status tanah hibah dan luas bangunan 252 $\mathrm{M}^{2} 10$ beralamat di Tepi Selo Lintau Buo.

Keberadaan Komite Sekolah harus bertumpu pada landasan partisipasi masyarakat dalam meningkatkan kualitas pelayanan dan hasil pendidikan di sekolah. Oleh karena itu, pembentukannya harus memperhatikan pembagian peran sesuai posisi dan otonomi yang ada. Adapun peran yang dijalankan Komite Sekolah adalah sebagai berikut : a) Pemberi pertimbangan (advisory agency) dalam penentuan dan pelaksanaan kebijakan pendidikan di satuan pendidikan, b) Pendukung (supporting agency), baik yang berwujud finansial, pemikiran maupun tenaga dalam penyelenggaraan pendidikan di satuan pendidikan, c) Pengontrol (controlling agency) dalam rangka transparansi dan akuntabilitas penyelenggaraan dan keluaran pendidikan di satuan pendidikan, d) Mediator antara pemerintah (eksekutif) dan Dewan Perwakilan Rakyat Daerah (legislatif) dengan masyarakat disatuan pendidikan

Komite sekolah mempunyai penjabaran peran dalam kegiatan operasional komite sekolah, adapun penjabarannya adalah sebagai berikut:

a. Peran Komite Sebagai Pemberi Pertimbangan (advisory agency).

Indikator kinerjanya peran komite sekolah sebagai pemberi pemberi pertimbangan adalah dengan memberikan masukan dan pertimbangan mengenai; Kebijakan pendidikan, Program Pendidikan, Rancangan Anggaran Pendapatan dan Belanja Sekolah (RAPBS), Kriteria kinerja satuan, Kriteria tenaga kependidikan, Kriteria fasilitas pendidikan. 
Berdasarkan hasil penelitian di atas dijelaskan bahwasanya peran komite sebagai pemberi pertimbangan dilakukan dalam proses penyusunan/perumusan RAPBS, program kerja tahunan/jangka pendek/ jangka menengah dan jangka panjang, hal itupun selama ini selalu dirasakan oleh Pondok Pesantren Modern Terpadu Tuanku Lintau, namun banyaknya pengurusn dan anggoata komite yang tidak aktif tentu pertimbangan tersebut masih akan lebih baik ketika seluruh pengurus dan anggota komite tersebut aktif sehingga mereka semua dapat berpartisipasi dalam memberikan pertimbangan terhadap RAPBS, porgram rutinitas, program tahunan atau jangka pendek, jangka menengah dan jangka panjang. Sehingga pelaksanaannya pun dapat dilakukan dengan semaksimal mungkin agar mendapatkan hasil yang lebih baik lagi. Ditambah lagi ketika pemberdayaan sumber dayapun dilakukan dengan lebih baik.

\section{b. Peran Komite Sekolah Sebagai Pendukung (Supporting Agency).}

Peran komite sebagai pendukung selama ini sangat dirasakan apalagi dalam percepatan pembengunan saranadan parasarana yang dibutuhakan oleh Pondok Pesantren Modern Terpadu Tuanku Lintau Pengelolaan karena tingkat partisipasi masyarakat sangat baik dalam dalam persoalan tersebut, namun beda halnya ketika dalam mendorong partispasi orang tua/wali santri dan santriwati untuk mendorong dan memberikan semangat serta motivasi bagi anak-anaknya yang nyantri di Pondok Pesantren Modern Terpadu Tuanku Lintau karena mereka beanggapan tuga pendidikan merupakan tanggung jawabg pondok pesantren seutuhnya dan kerana hal tersebutlah mereka memasukkan anaknya ke Pondok Pesantren, hal tersebut juga terlihat dari rendahnya partisipasi masyarakat untuk menyekolahkan anaknya ke Pondok Pesantren Modern Terpadu Tuanku Lintau ditambah rendahnya perhatian mereka ke Pondok Pesantren tersebut. Ketika perhatian masyarakat rendah untuk Pondok Pesantren Modern Terpadu Tuanku Lintau tentu sama halnya dengan perhataian/partisiapasi mereka dalam mewujudkan pendidikan yang bermutu di pondok pesantren tersebut.

Namun peran komite sebagai pendukung belumlah maksimal hal ini dilihat dari rendahnya partisipasi orang tua dalam memberikan semangat dan motivasi guan menunjang pendididikan anakanya, dan juga rendahnya partisispasi masyarakat terhadap Pondok Pesantren Modern Terpadu Tuanku Lintau seperti rendahnya perhatian/kepedulian mereka proses pendidikan di Pondok tersebut, dan juga rendahnya minat masyarakat untuk menyekolahkan anaknya di Pondok Pesantren tersebut. Namun disisi lain peran komite sebagai pendukung dalam persolan penganggaran sangat 
baik sehingga pondok bisa melakukan percepatan pembangunan mulai dari penambahan lokal belajar, asrama, MCK, dan renovasi bangunan.

\section{c. Peran Komite Sekolah Sebagai Pengontrol (Controlling Agency)}

Peran komite Pondok Pesantren Modern Terpadu Tuanku Lintau sebagai pengawas belumlah berjalan dengan cara yang maksimal karena hanya dilakukan sesekali atau kadang-kadang saja, dan dalam proses pemantauan juga jarang dilakukan hal ini dikarenakan banyaknya pengurus dan anggota komite yang tidak aktif.

Sedangkan untuk mengevaluasi hanya dilakukan ketika ada rapat evaluasi yang dilakukan Pondok Pesantren Modern Terpadu Tuanku Lintau bersama komite. Seharusnya agar organisasi bisa berjalan dengan lancar dan bekerja dengan maksimal tentu ketika semuanya berjalan sesuai dengan rencana dan job description masing-masing beda halnya dengan komite Pondok Pesantren Modern Terpadu Tuanku Lintau ini hanya hanya dilakukan oleh pengurus inti saja seperti ketua, sekretaris dan bendahara, beserta 2 sampai 3 orang anggotanya saja. Sehingga tidak seluruh program yang dapat diapantau atau diawasi secara langsung begitu juga dengan evaluasi dari setiap program yang dijalankan tersebut. d. Peran Komite Sekolah Sebagai Mediator.

Peran komite Pondok Pesantren Modern Terpadu Tuanku Lintau sebagai mediator sangat baik sehingga Pondok Pesantren Modern Terpadu Tuanku Lintau banyak mendapatkan bantuan dari berbagai pihak, begitu pula dalam rangka menampuang aspirasi, ide dan tuntutan yang datang dari masyarakat Pondok Pesantren Modern Terpadu Tuanku Lintau yang kemudian juga dianalisis dari setiap aspirasi, ide, ataupun tuntutan yang datang tersebut. Namun disisi lain masih terdapat kekurangan seperti masih minimnya minat masyarakat untuk menyekolahkan anakanya di Pondok Pesantren Modern Terpadu Tuanku Lintau.

\section{PENUTUP}

\section{Kesimpulan}

Berdasarkan hasil penelitian pada bab IV maka dapat disimpulkan bahwasanya:

a. Peran Komite Pondok Pesantren Modern Terpadu Tuanku Lintau sebagai pemberi petimbangan (advisory agency) belum berjalan dengan baik dikarenakan pengurus dan anggota komite Pondok Pesantren Modern Terpadu Tuanku Lintau masih banyak yang tidak aktif.

a. Peran Komite Pondok Pesantren Modern Terpadu Tuanku Lintau Sebagai Pendukung (Supporting Agency) cukup dirasakan oleh Pondok Pesantren Modern 
Terpadu Tuanku Lintau walaupun hanya beberapa orang saja yang berkerja.

b. Peran Komite Pondok Pesantren Modern Terpadu Tuanku Lintau Sebagai Pengontrol (Controlling Agency) kurang berjalan dengan baik sehingga banyak program yang tidak terpantau dan diawasi secara langsung.

c. Peran Komite Pondok Pesantren Modern Terpadu Tuanku Lintau Sebagai Mediator sudah baik dengan sehingga Pondok Pesantren Modern Terpadu Tuanku Lintau mendapatkan bantuan dari berbagai pihak.

\section{Saran}

Berdasarkan kesimpulan di atas, dapat disampaikan beberapa saran diantaranya sebagai berikut :

a. Bagi Ketua Komite Pondok Pesantren Modern Terpadu Tuanku Lintau hendaknya melakukan evaluasi kepengurusan Komite Pondok Pesantren Modern Terpadu Tuanku Lintau agar tidak berjalan sendiri lagi.

b. Bagi pengurus dan anggota komite Pondok Pesantren Modern Terpadu Tuanku Lintau hendaknya aktif dengan jabatan yang telah diamanahkan Pondok Pesantren Modern Terpadu Tuanku Lintau dan juga orang tua, masyarakat dll.

c. Bagi kepala Sekolah Menengah Pertama Pondok Pesantren Modern Terpadu Tuanku Lintau hendakanya memberikan masukan kepada komite Pondok Pesantren Modern Terpadu Tuanku Lintau yang tidak aktif agar aktif.

d. Bagi masyarakat sekitar Pondok Pesantren Modern Terpadu Tuanku Lintau hendaknya lebih memperhatikan lagi proses pendidikan di Pondok Pesantren Modern Terpadu Tuanku Lintau dengan cara memasukkan anak-anaknya ke Pondok Pesantren Modern Terpadu Tuanku Lintau dan juga memantau dan mengawasi proses pendidikan di Pondok Pesantren Modern Terpadu Tuanku Lintau.

\section{DAFTAR KEPUSTAKAAN}

Abdul Halim Hanafi, Metodologi Penelitian Kependiidkan Untuk Penulisan Skripsi, Tesis dan Disertasi, Batusangkar: STAIN Batusangkar Press, 2011

Abdul Rahmat, Public Relations For School. Bandung: MQS Publishing, 2009

Depdiknas. 2001. Manajemen Peningkatan Mutu Pendidikan Berbasis Sekolah (Buku 1). Jakarta : Depdiknas.

E.Mulyasa, Menjadi Kepala Sekolah yang Propesional, Bandung: PT.Remaja Rosada Karya, 2002

Keputusan Menteri Pendidikan Nasional Nomor : 044/U/2002 tanggal 2 April 2002 Tentang Dewan Pendidikan dan Komite Sekolah, 2002 
Lexy Moleong, Metodologi Penelitian Sutamto.2010. Peranan Komite Sekolah Kualitatif, Bandung:RemajaRosda dalam Meningkatkan Mutu Pendidikan Karya, 1966

Suharsimi Arikunto, Metode Penelitian Suatu

Pendekatan Praktek, Jakarta: Rineka Cipta, 1993 (http://sutamto.wordpress.com. Diakses 17 Juni 2011)

Umaedi. Manajemen Berbasis Sekolah. Jakarta: Depdiknas, 1999

Sukron, Peran Komite Madrasah Dalam

Pelaksanaan Manajemen Berbasis Sekolah, www, pendidikan.net, dalam Gooegle. com. 2005 